\title{
The Fish Theory-The Mind Set Gap in Human Resource Solution Complex
}

\section{Sujatha Siddappa*}

Head of Lab Medicine and Head of Pathology, Institute of Nephrology, Victoria Hospital Campus, Bangalore, India

*Corresponding Author: Sujatha Siddappa, Head of Lab Medicine and Head of Pathology, Institute of Nephrology, Victoria Hospital Campus, Bangalore, India.
Received: April 18, 2020

Published: May 02, 2020

(C) All rights are reserved by Sujatha

Siddappa.
The author has to her credit of being actively involved in human resource hiring practices very early on in her carrier and hence has her know how, to engage, encourage and enlighten in this siloed discipline. The core of the subject is the preamble to education versus emotional intelligence. The syllabus at formal education, this does not equip us to be productive in the larger picture. Abraham Lincoln-to quote "If given the truth, people can be depended to meet any kind of a national crisis. The great point is to bring them the real facts.

So, this article is dedicated to all the professionals on the high way or the path that she has travelled. What one does not see gets missed as what is not seen till it has reached a non-reconcilable situation. This is her version of light at end of the tunnel sharing.

She calls it a fish theory, fish are food as in revenue, fish are pets as in loving humans, fish are beautiful colourful front desk or face of your institute. The reasons for the nominal focused energy where the element of fish comes through. In an average fish their brain is $15 \%$ of the brain when compared to mammals and vertebrates. It's an approximate amount of your energy that should be used in resource management. This later information came from the ichthyologists who said that the fish have a very adaptive nature and effectively move in water they also have evolved colouring to help them evade from predators. The last but not the least cooking small fish is -it just has to be right amount very subtle or easily be an over kill like being over cooked fish. The fish gather information is by eves dropping very much akin to bush telegraph. The tipping point to learn a school of fish message corrective measures to make sure everyone is at school but subtly. In other words campus training.

The complexity of bringing together a blended work force. For an explicit example we have diversity that as in our case four generations working side by side. This further up scales the gap by working side by side, to be productive optimally as a team. An inclusive diverse team is like having a router and saying bring your own device policy. Any developing nation like ours will have a pyramid of migration workers, less traditional workers locally, and off shore arrangement are some of the challenges that typically present as work place organizational, chaos, conspiracy theory crapehanger - dilute your boundaries to build a fresh one. In other words flexibility is the new mantra. Today our prudence is on the test, the profit making centres have taken unprecedented steps and these are unprecedented times. Remember the world is a largely growing field and it's the in thing now-VUCA-as in Versatile, Uncertain, Complex and Ambiguous, in the administrators who are blue collared individuals on an uncertain platform. These are the days of Diversity a fair representation of hem line budget. MTM-moments that matter to MOT - moments of truth. To have the humility to respect and acknowledge the shadow task force- hackers, hustlers, hipsters and humanitarians.

Conversations of let's talk is in other words communicating skills. We need to face it that when it comes to a equitable culture cultivation the one size fits all does not feature in such conversations. Reasons the variables are many and hence vast to measure and control. These issues don't crop up like large waves and ebb down but are staggering as in constant and definitely not be of symbolic nature. It should be proactive, it should be one of total transparency and clarity of what is in store, what the efforts that are made and in return what is expected out of them. So, clarity, empathy and consistency in their communication in fact all their communications is a must. Clear empathetic consistent conversation is what makes managerial effectiveness in navigation in all weathers. This will happen only by being transparent and not pretending to be someone else. Its pleasure and agony-so choose well every little thing matters hang on there. It's never a contract obligation. Be a peoples person never be a bell jar dude-a quick what's your problem?

Critical thinking re looking at the situation is all that matters, along with evaluation. It Is not simple as being observative its more like cocktailing, a work place replete with gender, sexuality or class or societal. Authentic harness of the human resource power in its entirety in from as a whole. This can only happen when there is an environment of authenticity or the freedom to be one's self as they are. Organizations designated as stable are that are balanced and stable otherwise connotes organizational rigidity. There is also a view that organizations who are designed as stable with a mindset that reflects efficiency in a stable world with no surprises were "stupid together". It would be a triage situation. This also calls for what one would say 'intelligent disobedience'. The author also see some sort of pride in achievers who understand that the game changer is strong decisive, decision making carried through lived through experiences. 
How are things sorting out, creativity is a key, imagination is more important than knowledge, reason- knowledge is limited, and creativity encircles the world. Accept the situation and move swiftly the critical thinking here is make or break the situation. Every emergency stage situation veered from normal path will emerge a group which if unscathed will definitely gain wisdom. The happiness project is mandatory; you need to make an ambient productive environment.

Take home points seldom say never, seldom say yes, be a learning junkie, also show one to be honest radar or radar for honesty. Feasibility, flexibility and formulae oriented approach- intelligent disobedience. All opinions will be subjected to review by the environment. Why is honest sincerity important cause the one who knows the one who is aware will question so that's where it will stay. It will amount to 'work place accountability'.

All working places should be a $24 \times 7$ commitment. First self well being healthy mind, soul and body and then looking after others and after that academic archiving the triage of an administrator.

Office practice - - we are hospitality industry first and fore most of all.

Remember the fish also is in a world as in aquatic so leave no foot prints, that's all the more reason to share the fish theory. So human resource is like handling all the population of fishes in their own environment. Sea water fish, river fish, salt water fish, jelly fish, shark, the whale and the kissing gourami all in one environment. So you need to understand, be emotionally intelligent. They come in all forms fancy Asian arowana, scary piranhas, the long life of bigmouth buffalo or the semi social jelly fish and more. KYC-F: know your fish/ know your client. What works for one may not work for another. Awareness is the magic.

\section{The coach should be aware \#Give it}

$100 \%$

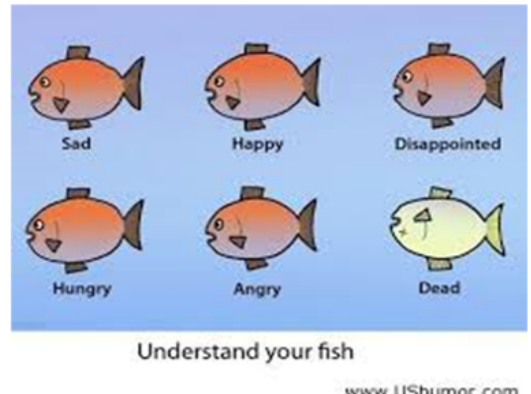

www.UShumor.com

Figure

\section{Acknowledgement}

These are rambling conversations with my friend Dr Rabjoth Kaur -MD microbiology PGI- Chandigarh now a full time wife and mother by choice and my colleague Dr vinay. K.S. Who thought these thoughts were worth sharing in print so this article. All credits will be forwarded to them.

\section{Assets from publication with us}

- Prompt Acknowledgement after receiving the article

- Thorough Double blinded peer review

- Rapid Publication

- Issue of Publication Certificate

- High visibility of your Published work

Website: https://www.actascientific.com/

Submit Article: https://www.actascientific.com/submission.php Email us: editor@actascientific.com

Contact us: +919182824667 